CASE REPORT

\title{
Scald injury from the Guthrie test: should the heel be warmed?
}

\section{Z Hassan, M Shah}

Arch Dis Child Fetal Neonatal Ed 2005;90:F533-F534. doi: 10.1136/adc.2005.072678

A 6 day old boy sustained scalds to his right foot from application of a "warm nappy" to increase blood flow to facilitate heel pricking for a routine Guthrie test. It is proposed that active warming of the heel in isolation is not necessary in heel blood sampling.

\section{CASE REPORT}

A 6 day old male baby was admitted to the burns unit at Booth Hall Children's Hospital with scalds to his right foot sustained while waiting to have a routine Guthrie test.

The midwife opted to use the "hot water in the nappy" technique to facilitate blood sampling from a heel prick. According to the midwife, this was a "standard" technique whereby a nappy soaked with warm water was wrapped around the heel for two to five minutes to cause vasodilatation, before the heel prick was performed. Soon after application of the "warm nappy", the baby screamed. When the midwife removed the nappy, she found blisters on the heel. The baby's mother promptly placed the right heel under cold running water, and the baby was then transferred to Booth Hall burns unit for further management.

On examination, the baby was found to have sustained mid-dermal scalds on the right foot and ankle totalling 1.5\% total body surface area. The wound healed with conservative management. However, the child has a residual dyspigmented, slightly raised scar at the site of the healed scald injury (fig 1). When last examined, six months after the injury, fortunately there were no functional problems.

\section{DISCUSSION}

The Guthrie test (newborn screening for phenylkeytonuria and thyroid function test) is performed when a child is 6 days old. Capillary blood sampling in neonates is generally through a heel prick. The heel is reasonably vascular and has relatively few nerve endings. The technique is simple, but is often performed incorrectly and may result in haemolysis ${ }^{12}$ pain, ${ }^{3}{ }^{4}$ and other complications. ${ }^{5}$

Prewarming the heel to increase blood flow is often recommended as part of heel preparation. ${ }^{67}$ This raises an important question: should the heel be warmed before capillary blood sampling? Several studies have shown no benefit of warming the heel before capillary blood sampling. ${ }^{8}$ The volume of blood, collection time, crying time, and repeat procedures have been shown to be no different between children who had their heel warmed and those who did not.

We undertook a telephone discussion with some senior midwives in the region, and the general consensus was that heel warming before blood sampling was not necessary. They felt that keeping the child in a warm room with clothes on for a few minutes was usually sufficient. However, if this were unsuccessful, then a visit on another day would be a better

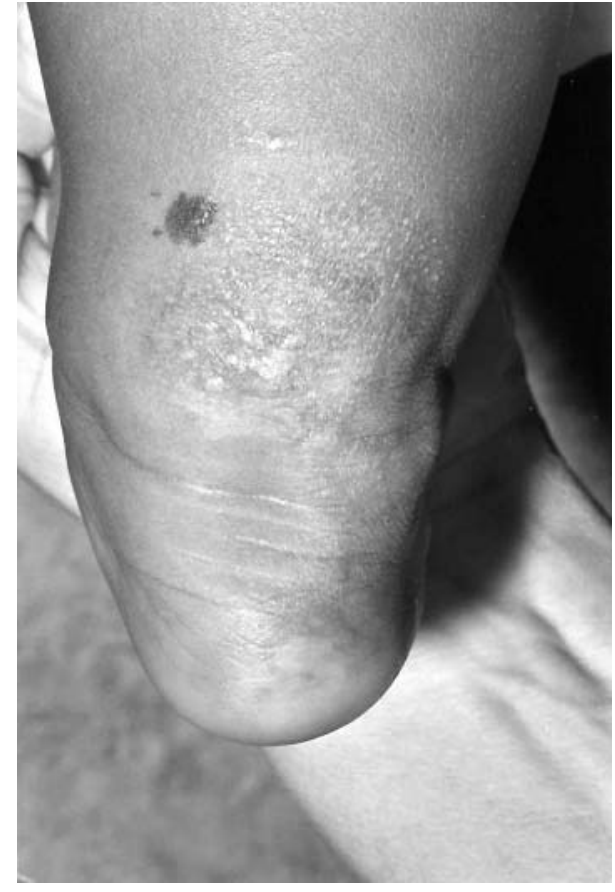

Figure 1 Right foot and ankle showing dyspigmented, raised scar resulting from scald injury. Permission for publication of this figure has been obtained from the parents.

option. Interestingly, we had designed a telephone questionnaire to find out practices in the community, but abandoned the idea as a memorandum was circulated to all the midwives in the region after this incident. We felt the response would be biased.

We propose that active warming of the heel in isolation is not important in heel blood sampling. More emphasis should be directed towards other factors, such as sampling devices and technique. ${ }^{10-12}$ The "hot water in nappy" technique should certainly be condemned.

\section{Authors' affiliations}

Z Hassan, M Shah, The Burns Unit, Booth Hall Children's Hospital, Central Manchester and Manchester, Children's NHS Trust, Charlestown Road, Blackley, Manchester M9 7AA, UK;

Competing interests: none declared

Permission for publication of fig 1 has been obtained from the parents.

Correspondence to: Mr Hassan, Department of Plastic Surgery, Booth Hall Children's Hospital, Charlestown Road, Blakeley, Manchester M9 7AA; zahid.hassan@man.ac.uk

Received 20 January 2005 


\section{REFERENCES}

1 Michaelsson $\mathbf{M}$, Sjolin S. Haemolysis in blood samples from newborn infants. Acta Paediatr Scand 1965;54:325-30.

2 Meites S, Lin SS, Thompson C. Studies on the quality of specimens obtained by skin puncture of children. 1. Tendency to haemolysis, and haemoglobin and tissue fluid as contaminants. Clin Chem 1981;27:875-8.

3 Owens ME, Todt EH. Pain in infancy: neonatal reaction to a heel lance. Pain 1984;20:77-86.

4 Grunau RV, Craig KD. Pain expression in neonates: facial action and cry. Pain 1987;28:395-410

5 Meehan RM. Heelsticks in neonates for capillary blood sampling. Neonatal Netw 1998;17:17-24.

6 Short BL. Capillary blood sampling. In Fletcher MA, Macdonald MG, eds. Atlas of procedures in neonatology. Philadelphia: J B Lippincott Co, 1993:97-100.
7 Meites S. Skin-puncture and blood-collecting technique for infants: update and problems. Clin Chem 1988;34:1890-4.

8 Barker DP, Willetts B, Cappendiik VC, et al. Capillary blood sampling: should the heel be warmed? Arch Dis Child Fetal Neonatal Ed 1996;74:F139-40.

9 Janes M, Pinelli J, Landry S, et al. Comparison of capillary blood sampling using an automated incision device with and without warming the heel. J Perinatol 2002;22:154-8.

10 Paes B, Janes $M$, Vegh P, et al. A comparative study of heel-stick devices for infant blood collection. Am J Dis Child 1993;147:346-8.

11 Barker DP, Latty BW, Rutter N. Heel blood sampling in preterm infants: which technique? Arch Dis Child Fetal Neonatal Ed 1994:71:F206-8.

12 Shah V, Taddio A, Kulasekaran K, et al. Evaluation of a new lancet device (BD QuikHeel) on pain response and success of procedure in term neonates. Arch Pediatr Adolesc Med 2003;157:1075-8. 